\title{
Induced p53 expression in lung cancer cell line promotes cell senescence and differentially modifies the cytotoxicity of anti-cancer drugs
}

\author{
Yingcai Wang, Giovanni Blandino, Moshe Oren and David Givol \\ Department of Molecular Cell Biology, Weizmann Institute of Science, Rehovot 76100, Israel
}

\begin{abstract}
The p53-null human lung cancer cell line H1299 was used in order to generate clones with ecdysone-inducible p53 as well as ecdysone-inducible p21 $1^{\text {wafl }}$. Induced expression of p53 resulted in irreversible cell growth arrest with characteristics of replicative senescence, suggesting that p53 can prevent immortalization by activating a senescence program. The effect of induced p53 and p21 warl expression on the cytotoxic action of the anti-cancer drugs etoposide and cisplatin was also analysed. Whereas p21 ${ }^{\text {wafl }}$ overexpression conferred increased resistance to killing by either drug, p53 overexpression enhanced the cytotoxic effect of cisplatin but protected against etoposide cytotoxicity. These results imply that the impact of p53 on susceptibility to chemotherapy may depend greatly on the particular drug and type of DNA damage. Moreover, these data demonstrate the importance of using isogenic cell lines to address this issue.
\end{abstract}

Keywords: inducible p53; senescence; anti-cancer drugs; p21 ${ }^{\text {wafl }}$

\section{Introduction}

The tumor suppressor gene p53 is mutated in more than half of all human tumors (Greenblatt et al., 1994) and p53-deficient mice are prone to multiple tumors at high frequency (Harvey et al., 1993a), indicating the important role of $\mathrm{p} 53$ in preventing tumorigenesis (Lane, 1992; Levine, 1997). Several cellular functions of wild type (wt) p53 were found responsible for this role. In response to radiation or genotoxic drugs, p53 mediates either growth arrest or apoptosis which prevent the replication of a mutated genome by either eliminating cells with DNA damage through programmed cell death or by allowing DNA repair to take place before DNA synthesis during $\mathrm{S}$ phase begins (for review see Gottlieb and Oren, 1996; Ko and Prives, 1996). Although p53-mediated apoptosis may be considered a major avenue for avoiding cancer, recent studies on a mouse model of colon cancer indicate that loss of p53 does not correlate with reduced apoptosis and that wt p53 can retard the progression of adenoma to carcinoma by mechanisms other than apoptosis (Fazeli et al., 1997). Such mechanisms may be related to p53-mediated growth arrest, particularly if this arrest becomes irreversible

Correspondence: D Givol

Received 11 February 1998; revised 6 May 1998; accepted 6 May 1998 leading to replicative senescence (Smith and PereiraSmith, 1996; Atadja et al., 1995). In this way, p53 may preclude illegitimate continuous cell replication and immortalization. The choice between apoptosis and growth arrest in response to p53 activation is not fully understood and depends on cell type and stage (Hansen and Oren, 1997).

Cells derived from p53 deficient mice readily become immortalized in culture and several reports implicate p53 in senescence of fibroblasts and other cell types (Harvey et al., 1993b; Tsukada et al., 1993; Bond et al., 1994, 1996; Shay et al., 1991; Hara et al., 1991; Serrano et al., 1997). Hence senescence may be an alternative mechanism for tumor suppression by $\mathrm{p} 53$. Indeed, a recent report demonstrated that p53 expression in the EJ human bladder carcinoma cell line leads to senescence (Sugrue et al., 1997).

To further understand how p53 may regulate the choice between growth arrest or senescence versus apoptosis we used the p53 null lung cancer cell line H1299 to generate clones in which expression of either p53 or p21 wafl can be induced by ecdysone (No et al., 1996). We report that induction of $\mathrm{p} 53$ overexpression in this system leads to irreversible growth arrest, accompanied by characteristic features of senescence.

The status of p53 also has important implications for the response of cells to chemotherapy. Recently, an extensive study of the response of 60 cancer cell lines of diverse origin to over 100 anti-cancer drugs revealed a significant correlation between p53 integrity and chemosensitivity (O'Connor et al., 1997). Such conclusion requires verification in isogenic systems consisting of the same cell line either expressing wt p53 or lacking p53 function. Here we analysed the effect of either induced $\mathrm{p} 53$ or $\mathrm{p} 21^{\text {wafl }}$ expression in combination with several anti-cancer drugs. We report that p53 may either antagonize or enhance drug-driven apoptosis, depending on the particular drug. On the other hand, p2 $1^{\text {wafl }}$ overexpression offered increased drug resistance irrespective of the drug. This system can be suitable for testing the effect of chemotherapy on isogenic cell populations differing only with regard to the presence or absence of wt p53.

\section{Results}

Ecdysone-induced expression of p53 and p21 wafl in H1299 cells

We utilized the recently described ecdysone-inducible system (No et al., 1996) to generate transcriptionallyinducible cell lines. The human lung cancer cell line H1299 (Takahashi et al., 1992) was chosen for this study since it is null for p53 owing to gene truncation 
(Bodner et al., 1992). Moreover, transfection with p53 was shown to lead to growth arrest of these cells as analysed by inhibition of colony formation (Chedid et al., 1994; Zakut and Givol, 1995). Ecdysone (muristerone)-inducible cell lines were generated in two steps. First, H1299 cells were transfected with pVgRXR followed by zeocine selection. Some 40 cell clones were isolated and transiently transfected with pIND/lacZ, maintained in the presence of muristerone and then stained with X-gal. Clone R-37 and R-38 were found to be the best inducible expressors of lacZ and were chosen for generating p53-expressing clones by transfection with $\mathrm{pIND} / \mathrm{p} 53$ followed by G418 selection. Western blot analysis with the DO-1 antibody was used to screen for inducible p53 expression. Clones C-30 and C-48 were found to express high levels of p53 and were used in further experiments. In a similar way clone R-38 was transfected with $\mathrm{pIND} / \mathrm{p} 21$ followed by G418 selection. This gave rise to clone W65, which was chosen for further work. Figure 1A shows the induction of p53 expression by various concentrations of muristerone and Figure 1B depicts the time course of induction in the C-30 clone. The data indicate that the cells are not leaky for p53 and that maximum expression is obtained at $1-2 \mu \mathrm{M}$ muristerone. This level is obtained at approximately $6-12 \mathrm{~h}$ after induction (Figure 1B), although significant p53 levels can be seen already as early as $3 \mathrm{~h}$ after induction with muristerone. The levels and kinetics of p53 expression correlate with the induction of endogenous p21 waf1, a target for transcriptional upregulation by p53 (Figure 1A and B). Analysis of mRNA expression in C-30 cells shows that the maximum levels of p53 and p21 wafl mRNA are reached at $9 \mathrm{~h}$ and $12 \mathrm{~h}$, respectively, after muristerone addition (data not shown). We also compared the level of induced $\mathrm{p} 21^{\text {waf1 }}$ in C-30 cells with that obtained in the temperature-sensitive cell line H1299 Val135\#3 and found that the transcriptional induction of p53 by muristerone in C-30 cells and the temperature-based activation of p53 in $\mathrm{H} 1299$ val135\#3 cells resulted in similar p21 $1^{\text {waf1 }}$ expression levels (data not shown). When muristerone-treated C-30 cells were subjected to immunofluorescent staining with antibody DO-1, approximately $90 \%$ of the cells stained for nuclear p53 after $12 \mathrm{~h}$ of muristerone induction (data not shown).

Clone W-65, expressing inducible p $21^{\text {wafl }}$, was used to analyse muristerone-dependent induction of $\mathrm{p} 21^{\text {waf } 1}$ as shown in Figure 1C and D. The levels of muristerone-induced p $21^{\text {wafl }}$ were found to be comparable to, and perhaps even slightly lower than those produced by the endogenous $\mathrm{p} 21^{\text {wafl }}$ gene in response to muristerone-mediated p53 induction (Figure 1, compare $\mathrm{A}$ and $\mathrm{B}$ with $\mathrm{C}$ and $\mathrm{D})$.

\section{Growth arrest and senescence induced by overexpression} of p53 in H1299 cells

The effect of induced p53 on C-30 cells grown in the presence of muristerone $(2 \mu \mathrm{M})$ was analysed by several parameters. As shown in Figure 2, p53 arrested the growth of C-30 cells in the presence of muristerone, while no growth arrest was seen in R38 cells used as a control for non specific effects of muristerone. As shown below (Figure 5), the arrest was associated with a modest increase in the fraction of cells found in the $\mathrm{G} 2$ phase of the cell cycle. To investigate the reversibility of the growth inhibition by $\mathrm{p} 53$, cells were incubated in the presence of muristerone for various time periods, and then muristerone was removed and the cells were allowed to grow again and form colonies. To that end, approximately $100 \mathrm{C}-30$ cells were plated in a $60 \mathrm{~mm}$ dish in the presence of muristerone. Muristerone was left in the culture for the number of days indicated in Figure 3 and was then replaced
A.

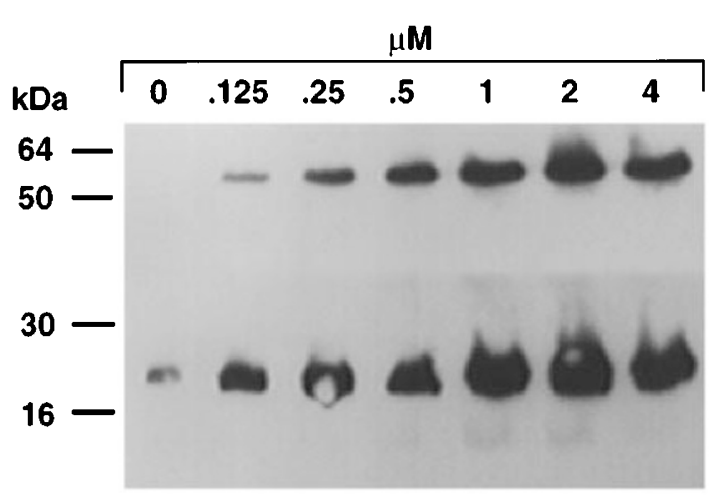

C.

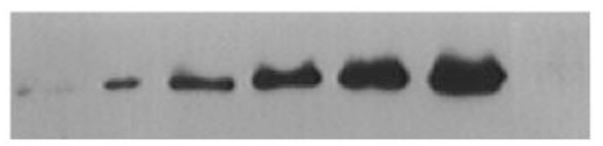

B.

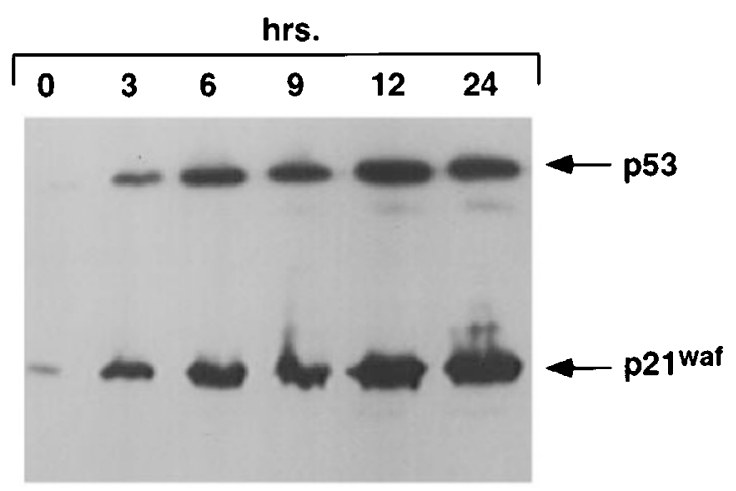

D.

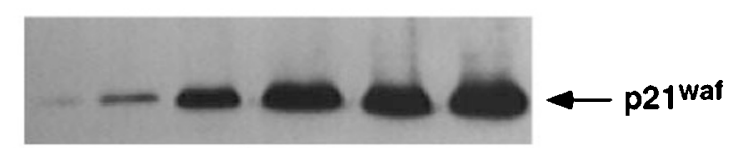

Figure 1 Muristerone-induced expression of p53 and p2 $1^{\text {waf1 }}$ in H1299 cells. Immunoblot analysis of cell lysates. (A) p53 and p2 $1^{\text {waf1 }}$ levels in C-30 cells incubated for $24 \mathrm{~h}$ in the presence of the indicated muristerone concentrations. (B) p53 and p2 $1^{\text {waf } 1}$ levels in C-30 cells incubated in the presence of $2 \mu \mathrm{m}$ muristerone for the indicated time periods. (C) Levels of p21 waf1 in W-65 cells incubated with the indicated concentrations of muristerone. Note that $4 \mu \mathrm{M}$ was not tested in this experiment. (D) Levels of p21 $1^{\text {waf } 1}$ in W-65 cells at different times after addition of muristerone $(2 \mu \mathrm{M})$ 
by regular culture medium. In each case, colonies were scored 10 days after removal of muristerone. As is evident from Figure 3, muristerone-mediated p53 induction irreversibly suppressed the ability of

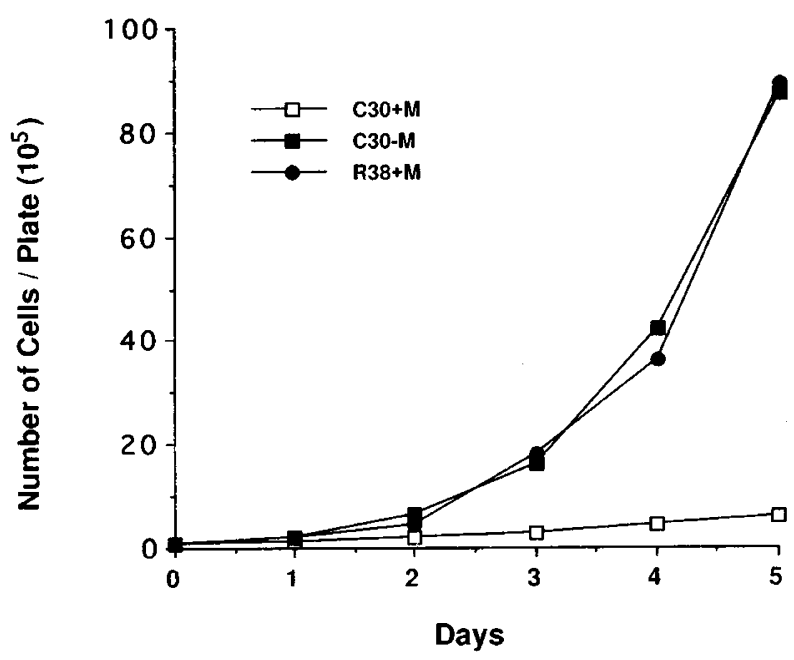

Figure 2 Growth curves of C-30 cells grown in the absence or presence of muristerone. Log-phase cells were seeded at $10^{5}$ cells per $60 \mathrm{~mm}$ dish. After $12 \mathrm{~h}$ the medium was changed to medium containing either $2 \mu \mathrm{M}$ muristerone or no muristerone. R-38 cells are $\mathrm{H} 1299$ cells transfected with $\mathrm{pVgRxR}$ only (used to generate $\mathrm{C}-30$ ), grown in the presence of $2 \mu \mathrm{M}$ muristerone
C-30 cells to form growing colonies. After four days in the presence of muristerone the number of recoverable clones was reduced to $25 \%$, and after 10 days to only $9 \%$ of the number obtained in un-treated cultures. In contrast, no reduction in the number of clones was observed when the parent clone R-38 was treated with muristerone (Figure 3A).

The irreversible arrest raised the possibility that excess p53 is driving H1299 cells into senescence. To test this notion more directly, the expression of the senescence associated marker $\beta$-galactosidase (SA- $\beta$ gal) was monitored following p53 induction. SA- $\beta$-gal was shown previously to be associated with senescent cells in vitro and in vivo (Dimri et al., 1995) and is also induced in EJ cells with tetracyclin-regulated p53 (Sugrue et al., 1997). As seen in Figure 4 significant induction of this enzyme was found in C-30 cells cultivated for 4 days with muristerone. Therefore, similar to previous reports (Atadja et al., 1995; Smith and Pereira-Smith, 1996; Sugrue et al., 1997), our results indicate that the growth inhibition of H1299 cells by p53 is at least in part irreversible due to replicative senescence. Interestingly, SA- $\beta$-gal activity was significantly more prominent in cells treated with muristerone in the presence of $10 \%$ serum as compared to $0.5 \%$ serum (data not shown). Hence, it is conceivable that induction of senescence requires cooperation between p53 and some signals generated by serum factors.

A

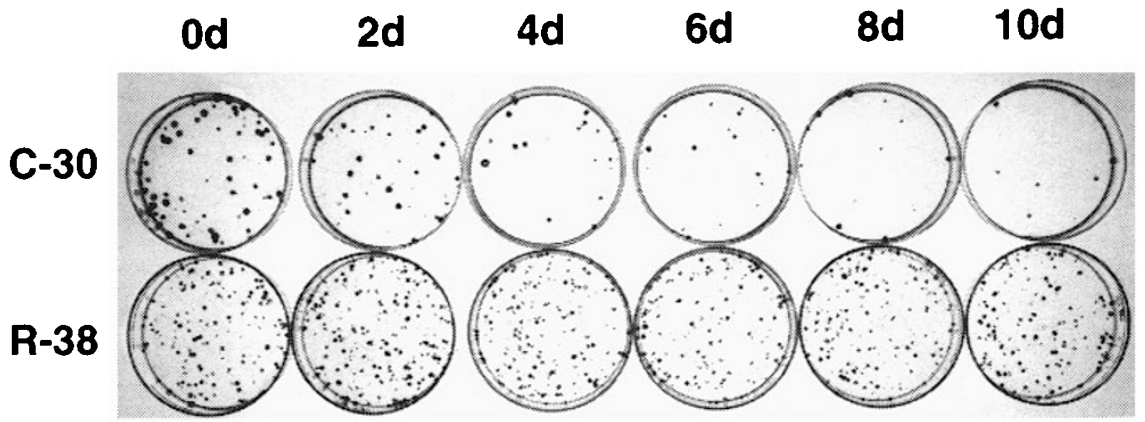

B

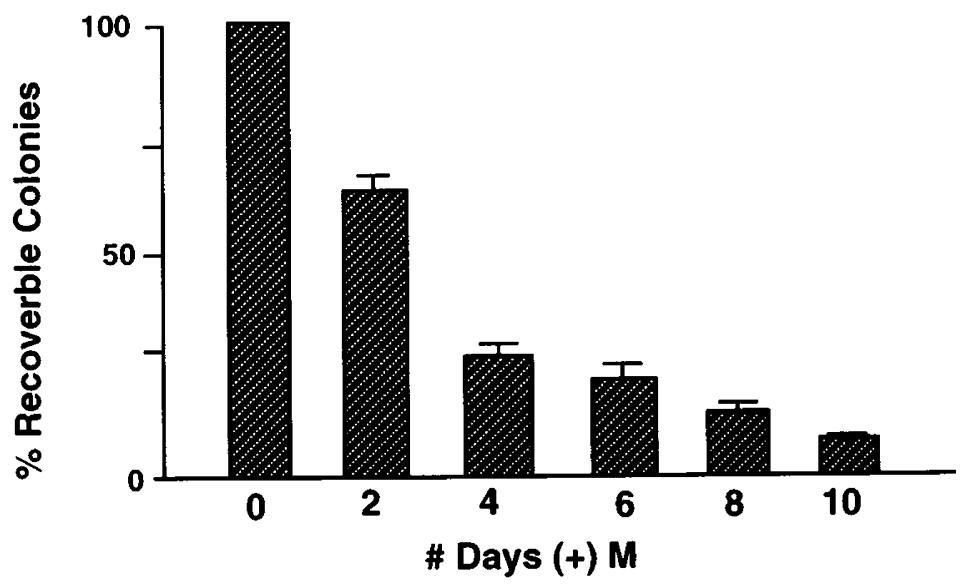

Figure 3 Colony growth inhibition by transient induction of p53 in C-30 cells. (A) C-30 and R-38 cells were seeded at a density of 100 cells $/ 60 \mathrm{~mm}$ dish. Muristerone was added one day later and maintained for the indicated number of days followed by 10 days of cultivation in the absence of muristerone. Colonies were stained with crystal violet. (B) Graphic representation of the colony formation efficiency data (C-30 cells). The percentage of recovered colonies was normalized relative to the control dishes without muristerone 
In conclusion, our results suggest that in addition to promoting growth arrest and apoptosis p53 can also drive cells into replicative senescence, thereby serving as a safeguard against cell immortalization.

\section{Effect of p53 and p21 waft overexpression on the cellular response to anti-cancer drugs}

Extensive p53 overexpression has been shown to cause apoptosis in H1299 cells (Haupt et al., 1996; Chen et al., 1996; Kagawa et al., 1997). In the two clones analysed by us, C-30 and C-48, we did not observe significant $\mathrm{p} 53$-induced apoptosis and induction of p53 did not cause any detectable increase in the number of cells with sub-G1 DNA content (Figure 5). Hence, the extent of p53 induction in these clones is probably not high enough to elicit apoptosis in the absence of additional stimuli. The effect of muristerone $(\mathrm{M})$ alone (Figure 5A) is slightly different between C-30 (p53 expression) and W-65 (p21 waf1 expression). In both cases there is an increase in the G1 population, whereas in p53 expressing line there is also an increase in the G2 population. The most important results of the growth arrest by both p53 and p21 is the marked reduction in the $\mathrm{S}$ phase population. This is similar to the result obtained with tetracycline-regulated p53 in H1299 cells (Chen et al., 1996).

We next wished to study the effect of p53 overexpression on the cellular response to genotoxic agents. Two drugs with different mechanisms of action, etoposide and cisplatin (O'Connor et al., 1997), were chosen for this purpose. Treatment of uninduced C-30 cells with etoposide results in extensive apoptosis reflected by a dramatic increase in the sub-G1 fraction and disappearance of cells in the G1 phase (Figure 5A). Surprisingly, induction of p53 by muristerone concomitantly with etoposide treatment did not augment apoptosis, but rather resulted in a marked protection of C-30 cells against apoptosis. The sub-G1 fraction was reduced from $33 \%$ to $12 \%$ (Figure $5 \mathrm{~A}$ ). A similar picture was revealed by trypan blue staining of dead cells (Figure 5B). To find out whether this protective effect might be related to the induction of p21 $1^{\text {wafl }}$, we analysed also W-65 cells expressing inducible $\mathrm{p} 21^{\text {wafl }}$. As shown in Figure 5 induction of p2 $1^{\text {waf } 1}$ in these cells also provided protection against etoposide-mediated apoptosis; the sub-G1 fraction was reduced from 23 to $14 \%$ which was correlated in the reduction of the \% of dead cells (Figure 5B). The similar behavior of $\mathrm{C}-30$ and $\mathrm{W}-65$ suggests that induction of $\mathrm{p} 21^{\text {wafl }}$ expression, either via p53 (in C30) or directly by muristerone (in W-65) is responsible in both cell lines for protection against apoptosis.

A completely different effect of p53 overexpression was revealed when $\mathrm{H} 1299$ cells were exposed to cisplatin (CDDP). Treatment of C-30 cells with CDDP for $48 \mathrm{~h}$ resulted in a significant extent of apoptosis as indicated by the accumulation of a substantial sub-G1 population $(14.5 \%)$; approximately $28 \%$ of the cells were dead at this point as determined by trypan blue staining (Figure 6B) and confirmed by propidium iodide uptake into non-permeabilized cells followed by FACS analysis (data not shown). As seen in Figure 6A, p53 overexpression increased significantly the sub-G1 fraction in the CDDP-treated population (from 14.5-34.6\%). Similarly, the percentage of dead cells increased from $28-41 \%$ (Figure 6B). Hence, in accordance with a recent drug screen report (O'Connor et al., 1997), wt p53 overexpression renders H1299 cells more sensitive to CDDP cytotoxicity. On the other hand, $\mathrm{p} 21^{\text {wafl }}$ overexpression had exactly the opposite effect and protected H1299 cells from CDDP-mediated cytotoxicity; the sub-G1 fraction was reduced from 13.7 to $4.1 \%$ (Figure $6 \mathrm{~A}$ ) and the percentage of dead cells went down from 25 to $12 \%$ (Figure 6B). These results suggest that whereas $\mathrm{p} 21^{\text {wafl }}$ has an antiapoptotic effect in both CDDP and etoposide treated cells, p53 may have opposing effects on the sensitivity to each of these drugs, conferring protection against etoposide cytotoxicity but enhancing CDDP cytotoxicity. It should be noted that the assay in this study was a short-term assay and it will be interesting to see if the protection from apoptosis is also seen in long-term colony survival assay. Our findings demonstrate the
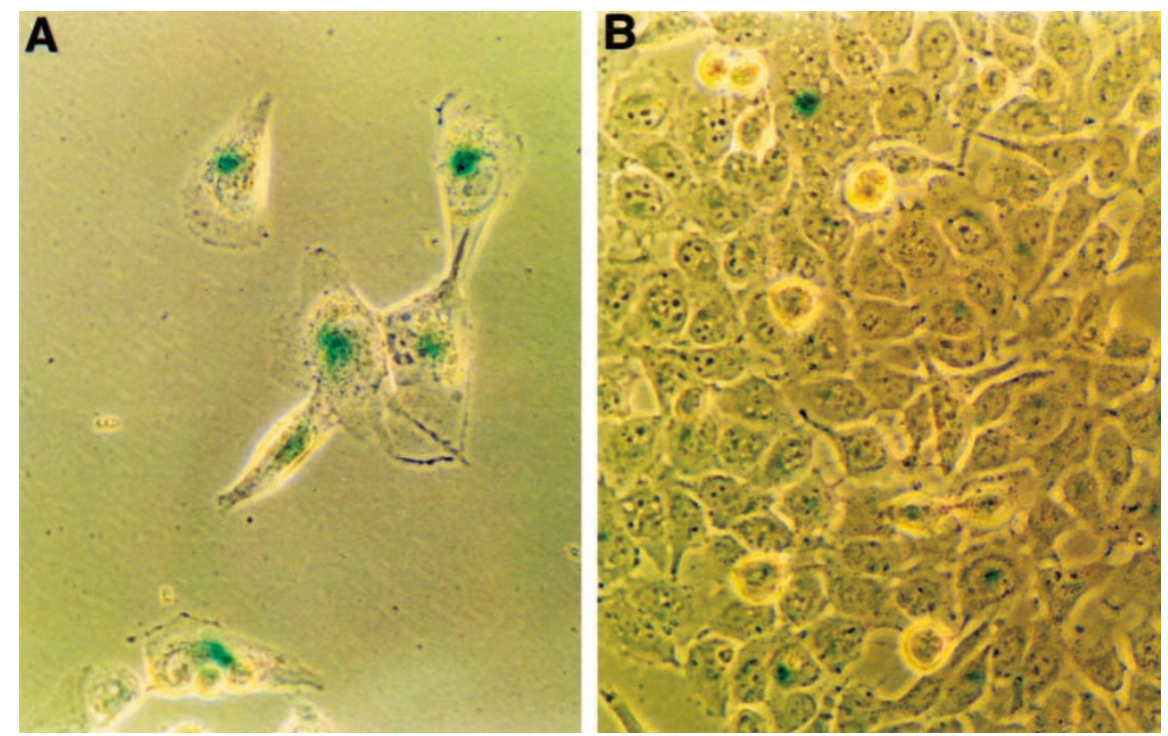

Figure 4 SA- $\beta$-gal staining of C-30 cells induced to express p53. C-30 cells were seeded at a density of $2 \times 10^{5}$ cells per 100 -mm dish and $12 \mathrm{~h}$ later the medium was replaced with a medium containing $2 \mu \mathrm{M}$ muristerone (A) or without $2 \mu \mathrm{M}$ muristerone (B). Four days later the cells were washed, fixed and stained for SA- $\beta$-gal (Dimri et al., 1995) for $16 \mathrm{~h}$ and then photographed using a Zeiss axiophot microscope 


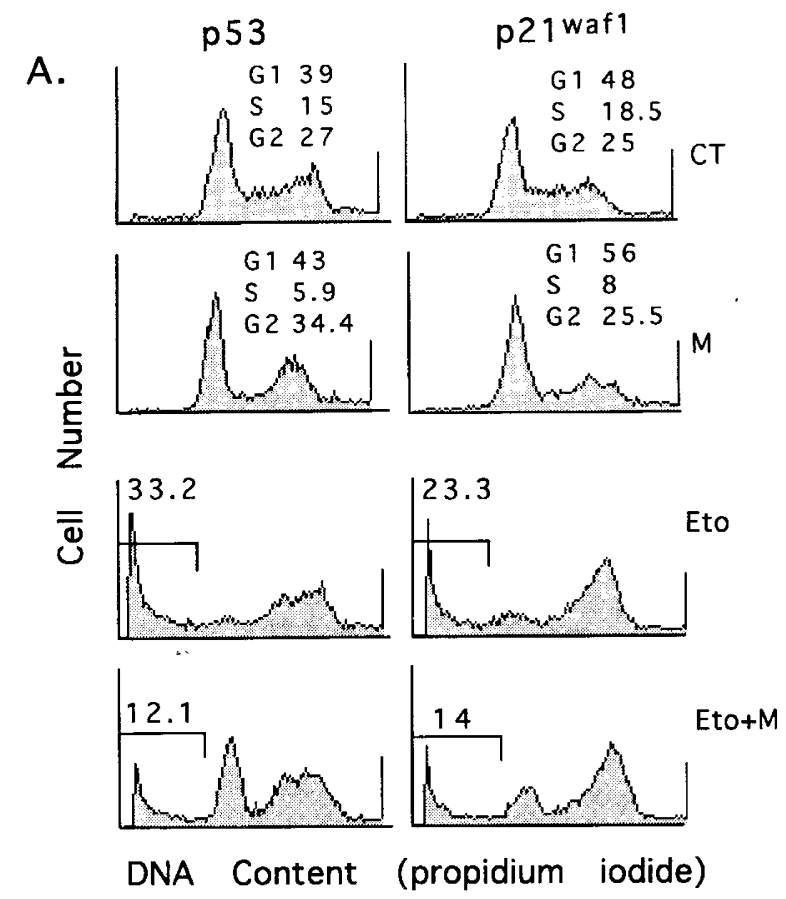

B.

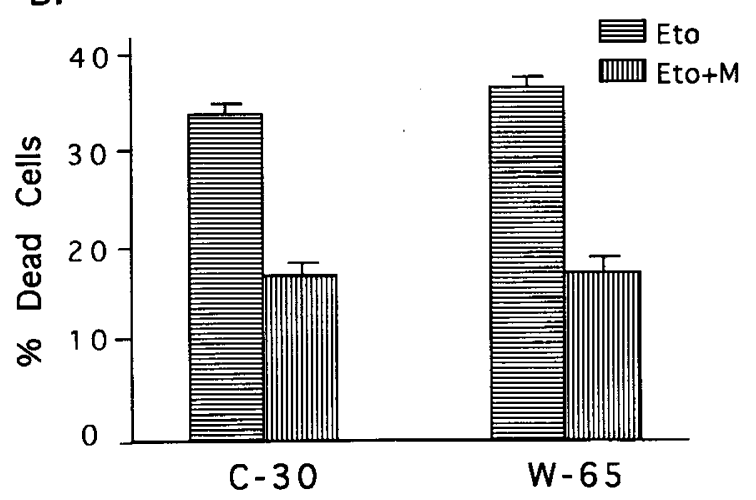

Figure 5 Etoposide cytotoxicity in H1299 cells is antagonized by p53 and p $21^{\text {wafl }}$ expression. C-30 cells and W- 65 cells were seeded at $5 \times 10^{5}$ cells $/ 100 \mathrm{~mm}$ dish. After $8 \mathrm{~h}$ the medium was replaced to contain etoposide $(5 \mu \mathrm{M})$ with or without muristerone $(2 \mu \mathrm{M})$. After $48 \mathrm{~h}$ floating cells were collected, spun down and combined with trypsinized adherent cells. The cells were resuspended in a total volume of $1 \mathrm{ml}$, of which $50 \mu \mathrm{l}$ was used for trypan blue staining and dead cell counting while the rest was used for cell cycle analysis in the FACS. (A) Cell cycle analysis of C-30 (p53) and W-65 (p21 $\left.{ }^{\text {wafl }}\right)$ cells after $48 \mathrm{~h}$ of treatment. The percentage of cells with sub-G1 DNA content is shown. The percentage of cells in the G1, S and G2 phases of the cell cycle is given for the control and muristerone treated cells. (B) Dead cell counts of C30 or W-65 under the same conditions as in A. CT - control; M muristerone; Eto - etoposide

value of isogenic cell lines for testing the effect of p53 on the response to chemotherapy, and indicate that the effect of p53 on the outcome of anticancer drug treatment may depend on the particular choice of drugs, as well as on cell type and endogenous p53 levels.

\section{Discussion}

In this study, we have used the recently described ecdysone-regulated expression system to study the
A.

$$
\text { p53 }
$$$$
\text { p21waf1 }
$$

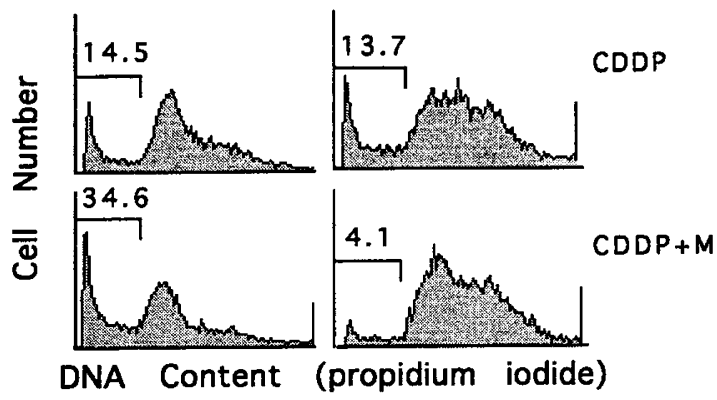

B.

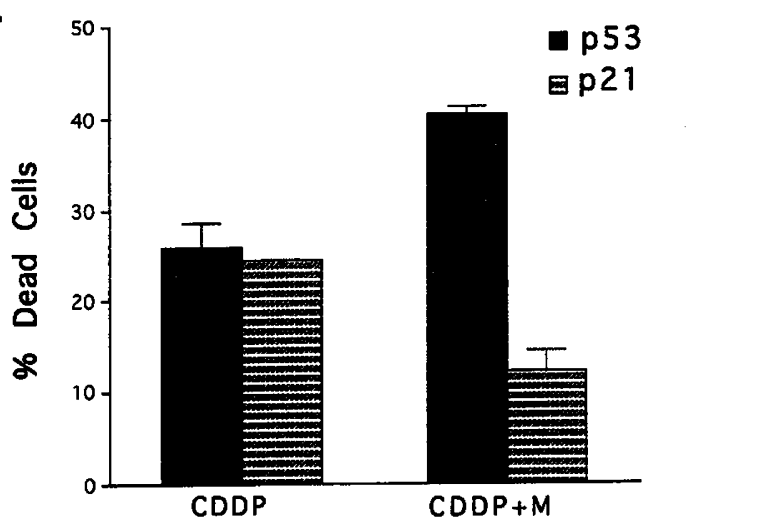

Figure 6 p53 expression enhances CDDP cytotoxicity whereas p2 $1^{\text {waf } 1}$ expression antagonizes CDDP cytotoxicity. C-30 or W-65 cells were seeded at $5 \times 10^{5}$ cells $/ 60 \mathrm{~mm}$ dish. After $8 \mathrm{~h}$ the medium was replaced to contain CDDP $(2.5 \mu \mathrm{g} / \mathrm{ml})$ with or without muristerone $(2 \mu \mathrm{M})$. Cell cycle analysis and counting of dead cells by trypan blue staining were performed as in Figure 5. (A). Cell cycle analysis of CDDP treated C-30 (p53) and W-65 (p21 $1^{\text {wafl }}$ ) cells in the presence or absence of muristerone. The percentage of cells with sub-G1 DNA content is shown. (B) Dead cell counts of C-30 or W-65 under the same conditions as in A

effect of conditional expression of either p53 or p21 $1^{\text {wafl }}$ in human H1299 lung adenocarcinoma cells. Previous studies using a temperature sensitive p53 mutant in rodent fibroblasts revealed that the growth arrest conferred on cells by induction of wt p53 activity at $32^{\circ} \mathrm{C}$ was reversible (Michalovitz et al., 1990; Martinez et al., 1991). By contrast, the growth arrest conferred by p53 on H1299 cells was found to become largely irreversible within 2-4 days of p53 overexpression, as measured by inhibition of colony formation (Figure 3). Moreover, the growth arrested cells exhibit characteristic features of senescence. These different effects of p53 may be partially explained by the use of different cell types. For instance, induction of p53 by DNA damage causes only a transient cell cycle arrest in rodent fibroblasts, but a permanent arrest in human fibroblasts (Linke et al., 1997).

The extent of p53 overexpression can also be a crucial determinant of the biological outcome. Experiments making use of tetracycline-regulated p53 expression in H1299 cells have demonstrated that the level of p53 expression can determine whether the cells will undergo apoptosis (high p53 expression) or growth arrest (low p53 expression) (Chen et al., 1996). Similar conclusions were reached in a study using recombinant p53 expressed from a vaccinia virus (Ronen et al., 1996). In our study, no evidence of apoptosis was observed in response to muristerone-induced p53 
expression, suggesting that the extent of p53 overexpression obtained by these cells is relatively moderate and probably more compatible with physiologically relevant situations.

Induction of senescence in human tumor-derived cells by p53 overexpression was also reported by Sugrue et al., (1997), using the bladder carcinoma EJ cell line. Such p53-mediated senescence may be an important mechanism to prevent cells from progressing to a state of unlimited proliferation, thereby serving as a viable alternative to apoptosis. Conversely, loss of p53 function would favor continued cell proliferation, a conclusion supported by the fact that fibroblasts from $\mathrm{p} 53$-deficient mice more readily become immortalized in culture (Tsukada et al., 1993; Bond et al., 1994). Therefore, along with growth arrest and apoptosis, replicative senescence may be considered as an additional distinct mechanism through which p53 can exert its tumor suppressor function. Unlike the transient growth arrest induced by p53 in certain cell types, induction of senescence implies that such cells will remain excluded from the replicative pool even when the stress signal which triggered the p53 response is over. In cells which have a relatively limited DNA repair capacity or are approaching the end of their replicative lifespan anyway, it may be safer to opt for irreversible senescence rather than take the risk of reentering the cell cycle with only partially repaired damage. The broad relevance of senescence to p53mediated tumor suppression is also suggested by a recent study on colon cancer in mice (Fazeli et al., 1997).

The inducible p53 system allows a comprehensive analysis of the relationship between p53 expression and the cellular response to DNA damage caused by anticancer drugs. This matter is of great potential importance because of its relevance to the making of cancer chemotherapy decisions. Since changes in p53 are common in human tumors, it is obvious that the detailed understanding of the relationship between p53 status and drug sensitivity is required in order to make better choices of chemotherapy. A recent study by the Developmental Therapeutic Program of the National Cancer Institute (O'Connor et al., 1997), using 60 cell lines and 123 standard anti-cancer drugs, revealed that mutant p53 cell lines tend to be less sensitive than wt p53 lines to most drugs (e.g. cisplatin and 5fluoroaracil). Our results using two drugs (etoposide and cisplatin), which operate through different mechanisms, show that in the case of cisplatin p53 indeed markedly increases the cytotoxic effect of the drug on H1299 cells. This effect might have been even more pronounced in the absence of p53-mediated p21 $1^{\text {wafl }}$ induction (see Figure 1), since induction of p21 waf1 alone (in W-65 cells) actually results in chemoprotection. It is thus conceivable that the enhancing effect of p53 on cisplatin-induced cytotoxicity will be particularly potent in tumor cells in which p2 $1^{\text {wafl }}$ induction either does not occur efficiently or is functionally ineffective (e.g. when $\mathrm{Rb}$ is mutated). Indeed cells lacking p $21^{\text {wafl }}$ exhibit increased sensitivity to cisplatin (Fan et al., 1997) as well as to several other anti-cancer agents (Waldman et al., 1996).

In contrast to its pro-apoptotic contribution in the context of cisplatin treatment, p53 actually has a protective effect against etoposide-induced cell death.
This observation is at first glance very surprising, as it appears inconsistent with the general notion that the presence of wt p53 renders tumor cells more sensitive to killing by DNA damaging agents (Lowe, 1995). However, there are already precedents for an antiapoptotic effect of p53 in tumorigenic cells treated with certain chemotherapeutic agents (Malcomson et al., 1995; Vikhanskaya et al., 1995, 1996) and even in mouse fibroblasts (Lassus et al., 1996). Remarkably, the protective effect of p53 against etoposide-induced death is similar to that seen with $\mathrm{p} 21^{\text {wafl }}$ overexpression. It is thus conceivable that this protective effect of p53 is largely, if not completely, due to the induction of $\mathrm{p} 21^{\text {wafl }}$ expression, since the levels of $\mathrm{p} 21^{\text {wafl }}$ achieved in C-30 cells are comparable to those found in muristerone-treated W-65 cells (Figure 1) which exhibit a similar extent of etoposide resistance (Figure 5). This is also in line with the demonstration that p21 wafl protects against apoptosis (Polyak et al., 1996) and loss of p21 wafl potentiates apoptotic response induced by intrinsic or extrinsic means (Wang et al., 1997). The fact that there exists, nevertheless, a generally good correlation between p53 function and higher tumor chemosensitivity (Lowe, 1995) could be due to the existence of additional mutations in the $\mathrm{pRb}$ pathway in such tumors. If this pathway becomes defunct, either owing to $R b$ gene alterations or to mutations in upstream regulators of $\mathrm{pRb}$ activity, induction of p21 $1^{\text {waf1 }}$ by $\mathrm{p} 53$ may have no practical consequences. In that case, the only contribution of p53 activation will be to promote apoptosis, either through other target genes or through mechanisms independent of p53-specific transcriptional activation (Hansen and Oren, 1997).

The pro-apoptotic effect of p53 is revealed with cisplatin, but not with etoposide. The DNA damage induced by cisplatin, but not by etoposide, is recognized and repaired by the nucleotide excision repair (NER) machinery. In this respect, it is of note that the XPB and XPD helicases, central components of the NER machinery, interact directly with p53 and have been shown to play an important role in p53mediated apoptosis (Wang et al., 1996). The enhanced effect of p53 on cisplatin-induced apoptosis might therefore be due to a death promoting activity elicited only by drugs which promote interactions between p53 and the NER machinery.

In conclusion, our findings imply that the status of p53 may have different and even opposing effects on the cellular response to anti-cancer agents. Therefore, when evaluating cancer patients one cannot make simple generalized predictions about the relationship of p53 status to therapy outcome. Obviously, ability to make such predictions will require a more systematic analysis of experimental model systems, comparing different cell types and different drugs. In such analysis, isogenic cell lines of the type described here are likely to prove valuable.

\section{Materials and methods}

\section{Cell culture}

The H1299 human lung adenocarcinoma (Takahashi et al., 1992) was maintained in RPMI containing $10 \%$ fetal 
bovine serum (FBS). H1299-pVgRXR cells were maintained in the same medium containing zeocin $(100 \mu \mathrm{g} / \mathrm{ml})$. The H1299-p53 and H1299-p21 wafl cell lines were maintained in medium containing zeocin and G418 $(400 \mu \mathrm{g} / \mathrm{ml})$. To induce $\mathrm{p} 53$ or $\mathrm{p} 21^{\text {wafl }}$ expression, muristerone (a synthetic analog of ecdysone), was added to the medium (final concentration $2 \mu \mathrm{M}$ ). Growth curves were obtained from cell counts in the presence or absence of muristerone. Log-phase cells were seeded at a density of $10^{5}$ cells $/ 60 \mathrm{~mm}$ dish, and cells were counted for 5 days at $24 \mathrm{~h}$ intervals. The following cell lines were used in this study: R-38, H1299 transfected with pVgRXR expressing the ecdysone receptor; C-30, H1299 (R-38) transfected with $\mathrm{pIND} / \mathrm{p} 53$ expressing human wt p53; W-65, H1299 (R-38) transfected with pIND/p21 expressing human p21 waf1 and H1299 Val135\#3, a derivative of $\mathrm{H} 1299$ expressing a temperature sensitive mouse p53 mutant (S Wilder and $M$ Oren, unpublished).

\section{Plasmids and transfections}

Plasmids pVgRXR, pIND and pIND/lacZ were from Invitrogen (San Diego, CA, USA). pIND/p53 was prepared by cloning the HindIII/XbaI fragment of human wt p53 cDNA (1.3 kbp, gift of Dr T Unger) into pIND. $\mathrm{pIND} / \mathrm{p} 21$ was prepared by cloning the $0.5 \mathrm{kbp} \mathrm{BamHI}$ EcoRI fragment of human p21 wafl cDNA (Chedid et al., 1994) into pIND. H1299 cells were transfected with each plasmid using the calcium phosphate method. Clone selection was with zeocin $(100 \mu \mathrm{g} / \mathrm{ml})$ for $\mathrm{pVgRXR}$ and with G418 (400 $\mu \mathrm{g} / \mathrm{ml})$ for $\mathrm{pIND} / \mathrm{p} 53$ or $\mathrm{pIND} / \mathrm{p} 21$. Stable clones obtained by double selection were screened by immunoblotting using antibody DO-1 for p53 and C-19 (Santa Cruz) for $\mathrm{p} 21^{\text {waf1 }}$.

\section{Immunoblot analysis}

Total cell lysates were prepared by standard methods (Sambrook et al., 1989) and protein content was determined with the Bio-Rad protein assay kit (Bio-Rad). Samples containing $50 \mu \mathrm{g}$ total protein were subjected to either 10 or $15 \%$ SDS/PAGE and transferred to nitrocellulose membranes (BA.85, Schleicher and Schuell). The filter was blocked in $2.5 \%$ skim milk $/ 0.1 \%$ Tween 20 in PBS for 30 min followed by incubation with the specific antibody and detection with HRP goat anti-mouse IgG for DO-1 (Sigma) or goat anti rabbit IgG (Jackson Laboratories) for C-19, followed by ECL (Amersham).

\section{Cell staining}

Immunostaining for p53 was performed on cells grown on coverslips. The coverslips were washed with PBS, fixed with cold methanol for $30 \mathrm{~min}$ at $-20^{\circ} \mathrm{C}$ and stored in PBS at $4^{\circ} \mathrm{C}$. Cells were stained for p53 with the DO- 1 monoclonal antibody, followed by rhodamine-labelled goat anti-mouse IgG (Sigma). Senescence-associated $\beta$-gal (SA$\beta$-gal) staining was at $\mathrm{pH} 6.0$ as previously described (Dimri et al., 1995). Cells $\left(2 \times 10^{5}\right)$ were seeded in $100 \mathrm{~mm}$ dishes and after $12 \mathrm{~h}$ the medium was replaced with muristerone $(2 \mu \mathrm{M})$-containing medium. Four days later, the dishes were washed with PBS and fixed with $3 \%$ formaldehyde in PBS for $5 \mathrm{~min}$ at room temperature followed by one wash in PBS and stained for $16 \mathrm{~h}$ at $37^{\circ}$ as described (Dimri et al., 1995).

\section{Colony staining}

Cells were seeded at a density of 100 cells per $60 \mathrm{~mm}$ dish and maintained with or without muristerone for varying periods. After withdrawal of muristerone the cultures were maintained for 10 more days. Colonies were stained by addition of $0.5 \mathrm{ml}$ crystal violet solution for $30 \mathrm{~min}$ followed by washing, as previously described (Zakut and Givol, 1995).

\section{Cell cycle analysis}

Cells $\left(5 \times 10^{5}\right)$ were seeded on $100 \mathrm{~mm}$ dishes and $12 \mathrm{~h}$ later the medium was replaced by medium containing cisplatin $(2.5 \mu \mathrm{g} / \mathrm{ml})$ in the presence or absence of muristerone $(2 \mu \mathrm{M})$. After $48 \mathrm{~h}$ the floating cells were collected and the attached cells were trypsinized, collected and added to the floating cells. Cells were similarly treated with etoposide $(5 \mu \mathrm{M})$ in the presence or absence of muristerone. The cells were centrifuged, washed in PBS, resuspended in $1 \mathrm{ml}$ PBS, fixed in $5 \mathrm{ml}$ of cold methanol for $30 \mathrm{~min}$ at $-20^{\circ} \mathrm{C}$, centrifuged again, washed once with PBS and resuspended in $1 \mathrm{ml}$ PBS containing $50 \mu \mathrm{g} / \mathrm{ml}$ of RNase and $50 \mu \mathrm{g} / \mathrm{ml}$ propodium iodide (Sigma), and then analysed in a fluorescence-activated cell sorter (FACSORT, Becton Dickinson). Data were analysed using the Cellfit program.

\section{Northern blot analysis}

Total RNA was isolated by the TRIzol reagent (GIBCOBRL), according to the manufacturer's protocol. RNA was stored under ethanol. Aliquots containing $15 \mu \mathrm{g}$ RNA were electrophoresed through a 1\%-agarose-formaldehyde gel and transferred to a nylon membrane (Hybond $\mathrm{N}^{+}$, Amersham) followed by UV crosslinking in an autocrosslinker (Stratagene). Hybridization probes, labeled with ${ }^{32} \mathrm{P}$, were prepared using the Rediprime random primer labeling kit (Amersham). Hybridization was in $5 \times$ SSPE, $5 \times$ Denhardt's solution and $0.5 \%$ SDS at $65^{\circ} \mathrm{C}$. The final washing was in $0.1 \times \mathrm{SSC}, 0.1 \% \mathrm{SDS}$ at $65^{\circ}$ for $10 \mathrm{~min}$.

\section{References}

Atadja P, Wong H, Garkavstev I, Veilletee C and Riabowol K. (1995). Proc. Natl. Acad. Sci. USA, 92, $8348-8352$.

Bodner SM, Minna JD, D'Amico D, Carbone D, Mitsudomi T, Fedorko J, Buchhagen DL, Nau MM, Gadzar AF, and Linnoila RI. (1992). Cancer Res., 7, 743-749.

Bond J, Haughton J, Blaydes V, Gire D, Wynford-Thomas D and Wyllie F. (1996). Oncogene, 13, 2097-2104.

Bond JA, Wyllie FS and Wynford-Thomas D. (1994). Oncogene, 9, 1885-1889.

Chedid M, Michieli P, Lengel C, Huppi K and Givol D. (1994). Oncogene, 9, 3021-3024.

Chen X, Ko LJ, Jayaraman L and Prives C. (1996). Genes \& Develop, 10, $2438-2451$.

Dimri GP, Lee X, Basil, G, Acosta M, Scott G, Roskilley C, Medrano EE, Linskens M, Rubeli I, Pereira-Smith O, Peacocke M and Campisi J. (1995). Proc. Natl. Acad. Sci. USA, 92, $9363-9367$.

Fan S, Chang JK, Smith ML, Duba D, Fornace AJ and O'Connor PM. (1997). Oncogene, 14, $2127-2136$.

Fazeli A, Steen RG, Dickinson SL, Beutista D, Dietrich W, Bronson RT, Bresalier RS, Lander ES, Costa J and Weinberg RA. (1997). Proc. Natl. Acad. Sci. USA, 94, $10199-10204$

Gottlieb TM and Oren M. (1996). Biochem. Biophys. Acta, 1287, $77-102$. 
Greenblatt MS, Bennett WP, Hollstein M and Harris CC. (1994). Cancer Res., 54, 4855-4878.

Hansen R. and Oren M. (1997). Curr. Biol., 7, 46-51.

Hara, E, Tsurui H, Shinozaki A, Nakada S and Oda K. (1991). Biochem. Biophys. Res. Comm., 179, 528-534.

Harvey M, McArthur MJ, Montgomery Jr CA, Butel JS, Bradley A and Donehower LA. (1993a). Nature Genet., 5, $225-229$.

Harvey M, Sands AT, Weiss RS, Hegi ME, Weissman RW, Pantazin P, Giovanilla BC, Tainsky M, Bradley A and Donehower LA. (1993b). Oncogene, 8, 2457-2467.

Haupt Y, Barak Y and Oren, M. (1996). EMBO J., 15, $1596-1606$

Kagawa S, Fujiwara T, Hizula A, Yasuda T, Zhang WW, Roth JA and Tanaka N. (1997). Oncogene, 15, $1903-$ 1909.

Ko LJ and Prives C. (1996). Genes \& Dev., 10, 1054- 1072.

Lane DP. (1992). Nature, 358, 15-16.

Lassus P, Ferlin M, Piette J and Hibner U. (1996). EMBO J., 15, $4566-4573$.

Levine AJ. (1997). Cell, 88, 323 - 331.

Linke P, Clarkin KC and Wahl GM. (1997). Cancer Res., 57, $1171-1179$.

Lowe SW. (1995). Curr. Opin. Oncology, 7, 547-553.

Malcomson RDG, Oren M, Wyllie AH and Harrison DJ. (1995). Br. J. Cancer, 72, $952-957$.

Martinez J, Georgoff I, Martinez J and Levine AJ. (1991). Genes Dev., 5, 151-159.

Michalovitz D, Halevy O and Oren M. (1990). Cell, 62, 671 680.

No D, Yao TP and Evans RM. (1996). Proc. Natl. Acad. Sci. $U S A, 93,3346-3351$.

O'Connor PM, Jackman J, Bai I, Myers TG, Fan S, Mutoh M, Scudiero DA, Monks A, Sausville EA, Weinstein JN, Friend S, Fornace AJ and Kohn KW. (1997). Cancer Res., 57, $4285-4300$.
Polyak K, Waldman T, He TC, Kinzler KW and Vogelstein B. (1996). Gene Dev., 10, $1945-1952$.

Ronen D, Schwart D, Teitz Y, Goldfinger N and Rotter V. (1996). Cell Growth Differ., 7, 21-30.

Sambrook J, Fritsch EF and Maniatis T. (1989). Molecular Cloning - A Laboratory Manual. Cold Spring Harbor Lab. Press: Plainview, NY 2nd ed.

Serrano M, Lin AW, McCurrach ME, Beach D and Lowe SW. (1997). Cell, 88, 593-602.

Shay JW, Pereirasmith OM and Wright WE. (1991). Exp. Cell Res., 196, 33-39.

Smith JR and Pereira-Smith OM. (1996). Science, 273, 63 67.

Sugrue MM, Shin DY, Lee SW and Aaronson SA. (1997). Proc. Natl. Acad. Sci. USA, 94, $9648-9653$.

Takahashi T, Carbone D, Takahashi T, Nau, MM, Hida T, Limmoila I, Veda R and Minna JD. (1992). Cancer Res., 52, $2340-2343$.

Tsukada T, Tomooka Y, Takai S, Uida Y, Nishikawa S, Yagi T, Tokimaga T, Takeda N, Suda Y, Abi S, Matsuo I, Ikawa Y and Aizawa S. (1993). Oncogene, 8, 3313-3322.

Vikhanskaya F, D'Incalci M and Broggini M. (1995). Int. J. Cancer, 61, 397-401.

Vikhanskaya F, Erba E, Dincalci M and Broggini M. (1996). Exp. Cell Res., 227, 380-385.

Waldman T, Lengauer C, Kinzler KW and Vogelstein B. (1996). Nature, 381, 713-716.

Wang YA, Elson A and Leder P. (1997). Proc. Natl. Acad. Sci. USA, 94, 14590-14595.

Wang XW, Vermenlen W, Coursen JD, Gibson M, Lupold SE, Forrester K, Xu G, Elmore L, Yeh H, Haymakers JHJ and Harris CC. (1996). Genes \& Develop., 10, 1219- 1232.

Zakut R and Givol D. (1995). Oncogene, 11, 393-395. 